\title{
FIELD THEORY AND JUDICIAL LOGIC
}

\author{
FELIX S. COHEN $\dagger$
}

\begin{abstract}
"A new concept appears in physics, the most important invention since Newton's time: the field. It needed great scientific imagination to realize that it is not the charges nor the particles but the field in the space between the charges and the particles which is essential for the description of physical phenomena."*
\end{abstract}

\section{The Paradoxes of Judicial Logic}

\section{Are Lawyers Liars?}

ANyone who has read the statement of facts in a large number of briefs of appellants and appellees is likely to conclude that any resemblances between opposing accounts of the same facts are purely fortuitous and unintentional. The impression that opposing lawyers seldom agree on the facts is strengthened if one listens to opposing counsel in almost any trial. Now, as a matter of simple logic, two inconsistent statements cannot both be true. At least one must be false. And it is always possible that both are false, as, for example, when the plaintiff's attorney says the defendant speeded into the zone of the accident at sixty miles an hour and the defendant's counsel insists his client was jogging along at twenty miles an hour, while, in fact, he was moving at forty miles an hour. Thus, a logician may conclude that either (1) at least half of our practicing lawyers utter falsehoods whenever they open their mouths or fountain pens, or (2) that a substantial majority of practicing lawyers utter falsehoods on a substantial number of such occasions. If we define a liar as a person who frequently utters such falsehoods, ${ }^{1}$ it would seem to follow logically that most lawyers are liars.

How the edifice of justice can be supported by the efforts of liars at the bar and ex-liars on the bench is one of the paradoxes of legal logic which the man in the street has never solved. The bitter sketch of "Two Lawyers" by Daumier still expresses the accepted public view of the legal profession. So, too, does the oft-told story of Satan's refusal to mend the party wall between Heaven and Hell when it was his turn to do so, of St. Peter's fruitless protests and threats to bring suit, and of Satan's crushing comeback: "Where do you think you will find a lawyer?"

$\dagger$ Visiting Lecturer in Law, Yale Law School, and in Philosophy, City College of New York.

* Einstein \& Infeld, The Evolution of Physics 259 (1938).

1. To define a liar as a person who always lies would be to set standards practically incapable of human attainment. Even the most confirmed liar is likely to tell the truth sometimes. Otherwise, the people he talks to will not believe him and the purpose of his lying will not be accomplished. 
Of course, lawyers know that the popular opinion on these subjects is inaccurate. Lawyers have ample opportunity to know how earnestly two litigants will swear to inconsistent accounts of a single event. Lawyers thus have special opportunities to learn what many logicians have not yet recognized: that truth on earth is a matter of degree, and that, whatever may be the case in Heaven, a terrestrial major league batting average above .300 is nothing to be sneezed at.

The difference between the lawyer's and the logician's view of truth is worth more attention than it has had from either lawyers or logicians.

From the standpoint of rigorous logic, a proposition is either true or false. There is no middle ground. A statement such as "It is raining," which is true at one time and place and not at another, is ambiguous, and an ambiguous sentence is not a proposition, though each of its possible meanings may constitute a proposition. Indeed, the characteristic of being either true or false is commonly utilized in modern logic as the defining characteristic of propositions.

Life, unfortunately, is not so simple. Logicians may define propositions, but whether they can find or create propositions is another matter. Even if we convince ourselves that there are propositions, it does not necessarily follow that we can actually create them or find them; we may convince ourselves that there is, somewhere, an oldest man on earth, without ever being sure who he is.

One of the greatest modern logicians, Alfred North Whitehead, used to say: "We shall meet propositions in Heaven." By this he meant that the symbolism of terrestrial life is too fuzzy ever to reach absolute precision, so that unambiguousness is an ideal rather than an attainable fact. Every actual humanly constructed sentence has different shades of meaning to different readers. This is most likely to be the case in fields of controversy where different readers bring different examples, contexts, and values to bear on any given word. In any such situation a sentence will embody not a single proposition but several propositions which are ideally distinguishable. Some of these propositions may be true. Some may be false. The relation of true meanings to false meanings that flow from a single sentence generally involves a complicated quantitative distribution pattern. The simple, traditional true-false dichotomy is often quite useless.

Take, for instance, a typical humanly constructed sentence, one which has been uttered, down through some 3000 years, by hundreds of millions of human beings of many races, many tongues, and many religions:

The Lord is my shepherd; I shall not want.

What sense does it make to ask whether this sentence is true or false?

Of course, there may be literal-minded readers of the Bible who will insist that the sentence has only one "correct" meaning, which is true, and that any variant interpretation is simply erroneous. 
There are, no doubt, equally dogmatic individuals who will insist that the sentence is simply false. If they are dogmatic atheists, they will tell us: "There is no Lord, and therefore He cannot possibly be a shepherd." If they are Montana cattlemen, they may add that nobody in the sheep business could possibly deserve to bear the name of the Lord. Others there are who have outgrown the effort to make God in man's image, but still recite these words with full sincerity. To some such, the words of the Psalmist mean that the forces of evil are somehow self-defeating, that ultimate victory rests with the forces of righteousness, that none of us is self-sufficient, that none of us is capable of protecting himself against all the dangers that surround us from cradle to grave, and that sanity requires a faith in an unseen power that will protect us and guide us as a faithful shepherd guides his sheep, seeing that their wants are fulfilled. But one who thus translates the words of an ancient poet into the context of his own beliefs has no right to assume that this is the only context in which those words have significance. $\mathrm{He}$ will be content to say that they have truth for him.

This dependence of meaning upon a personal frame of reference is something that many of us take for granted when we refuse to argue over affirmations of religious faith. May not the same dependence of meaning and truth upon varying contexts be found in non-religious fields as well, even in the mundane fields which concern lawyers and their clients? May we not say, even, that law as, par excellence, the field of controversies, is the field in which the imposition of different meanings upon the same verbal formula is most characteristic and most significant?

If anybody asks us whether the first sentence of the Twenty-third Psalm is true or false, we may properly conclude that the interrogator is lacking in imagination and guilty of the fallacy of misplaced concreteness. That is because we realize that a sentence of this sort (and perhaps every other humanly constructed sentence, in greater or lesser degree) means many things to many minds. Perhaps, if we look closely enough, a sentence never means exactly the same thing to any two different people. For no two minds bring the same apperceptive mass of understanding and background to bear on the external fact of a sound or a series of marks. Indeed, I doubt whether any sentence means exactly the same thing to me the first time $I$ hear it that it means the tenth time or the hundredth time. Of course, for many practical purposes, we are disposed to overlook such variations of meaning. Each of us is likely to try to fix on a particular segment of our thinking, at a particular time, as "the real meaning" of any sentence. We may then consider all other interpretations as more or less serious aberrations. Perhaps we may be justified in holding that our own specific understanding of the sentence at a particular time is a proposition, and either false or true. But what, then, shall we say of the 
sentence as a social fact, a source of many interpretations, a matrix of many propositions? Must we not say that the truth of any assertion is a matter of degree, that from certain angles the sentence may give light and that at other angles it may obscure more light than it gives? The angle or perspective and the context are part of the meaning of any proposition, and therefore a part of whatever it is that is true or false.

The location of words in a context is essential to their meaning and truth. The fallacy of simple location in physical space-time has finally been superseded in physics. We now realize that the Copernican view that the earth moves around the sun and the older Ptolemaic view that the sun moves around the earth can both be true, and that for practical though not aesthetic or religious purposes the Ptolemaic and Copernican astronomics may be used interchangeably. ${ }^{2}$ We realize that Euclidean and non-Euclidean geometries can both be true. What is a straight line in one system may be an ellipse in another system, just as a penny may be round in one perspective, oval in a second, and rectangular in a third.

A prosecuting attorney who assumes that policemen are accurate and impartial observers of traffic speeds will arrive at one estimate of the speed of a defendant charged with reckless driving. The defendant's attorney, if he assumes that his client is an honest man and that policemen on the witness stand generally exaggerate in order to build up an impressive record of convictions, will arrive at another estimate. If each honestly gives his views the court will have the benefit of synoptic

2. "The new system had a great influence, for example, on men's general feelings regarding their place in the universe. It is certain that this influence did not originate from the fact that the new system was encouraging navigation, since for all practical purposes (such as navigation) it mattered very little whether the positions of the stars were calculated by the geocentric or by the Copernican system. In this respect the introduction of the new world system involved only a very slight correction.

"The influence of the Copernican system on the general feelings of men was not connected with the fact that it became a tool which simplified the calculation of the orbits of the stars, or calculation of some observable phenomena in general. What really mattered was quite a different feature of Copernicus' system. In this system the language and pictures used to represent observable facts were completely different from the language and pictures through which facts were represented by the geocentric world-system.

"The geocentric system formulated its propositions in terms such as, 'The earth is at rest while everything else is moving around it.' Copernicus, however, spoke of, 'an earth that is moving in a similar way to all the other celestial bodies.' Even if we could conclude exactly the same observable facts from both these systems, one difference would still remain: The geocentric system formulated its doctrine in a language which harmonized with the language used by the people of the Middle Ages to formulate their general feeling towards the Universe. Whereas Copernicus used a completely different language, suggesting a completely different feeling, for example a feeling that our earth and all the celestial bodies were of equal importance." Philipp Frank, The Position of Einstein's Theory of Relativity in the Evolution of Science, 9 J. of UNIFIEd SCIENCE (ERKENNTNIS) 170, 171 (1939). 
vision. Appreciation of the importance of such synoptic vision is a distinguishing mark of liberal civilization. To the anthropologist, the tolerance that is institutionalized in a judicial system geared to hear two sides in every case represents a major step in man's liberation from the tyranny of word-magic. If we do not feel that we have to annihilate those who say things we do not believe or, what is generally more irritating, say things we do believe but say them in strange ways or in unfamiliar accents, we are able to conserve our energy for more useful purposes. Energy so conserved may produce science, art, baseball, and various other substitutes for indiscriminate individualistic slaughter.

The disagreements of opposing lawyers on statements of simple fact, and the even wider disagreements that characterize their views on more complicated facts ("opinion" and "law"), call for a more humane and social view of truth and meaning than appears in most of the traditional logic books. This is not to say that the traditional logic books are wrong. It is only to say that so far the logicians, having concentrated their vision on the logical heavens where words continue at rest and mean the same thing forever, have not fully explored the imperfect efforts of human beings to communicate with each other. But there are welcome indications today that logicians are beginning to pay more attention to the real world where people seldom say exactly what they mean or mean all they say, where no two people ever quite understand each other, where the accumulation of different views of the same event is the only remedy we have found for fanaticism, and where the logic of fiction has a more direct bearing upon every-day discourse than the logic of science. ${ }^{3}$

In a certain sense, it is true that lawyers are liars. In the same sense, poets, historians, and map-makers are also liars. For it is the function of lawyers, poets, historians, and map-makers not to reproduce reality but to illumine some aspect of reality, and it always makes for deceit to pretend that what is thus illumined is the whole of reality. None of us can ever possibly tell the whole truth, though we may conscientiously will to do so and ask divine help towards that end. The ancient wisdom of our common law recognizes that men are bound to differ in their views of fact and law, not because some are honest and others dishonest, but because each of us operates in a value-charged field which gives shape and color to whatever we see. The proposition that no man should be a judge of his own cause embodies the ancient wisdom that only a many-perspectived view of the world can relieve us of the endless anarchy of one-eyed vision.

Thus, it happens that there are implicit in our judicial process certain attitudes towards truth and reality which have recently become ex-

3. See M. R. Cohen, A Preface to Logic, cc. 4, 5 (1944); Thouless, How to Think Straight (1948). 
plicit in physical science. The importance of Einstein's special and general theories of relativity is not that they make us see that motion is relative to an observation post. This was recognized long ago. The real importance of Einstein is his development of formulae by which many different accounts of the same physical event may be correlated with each other, so that from the position and direction of an event in any physical system we can calculate its position and direction in any other system. ${ }^{4}$ Einstein has made it possible for us to say that what is reported as a straight line in one system will be reported in another system as a curve of a defined form.

What is needed in law, if law is to become more scientific in the future than it has been in the past, is a body of learning from which we can predict that what looks like a straight story or a straight sale from one standpoint will look like a crooked story or a crooked sale from another, and from which we can predict the successive "distortions" that any observed social fact will undergo as it passes through different valuecharged fields in the "world-line" 5 of its history.

Concretely, if we see either of the following headlines, we should be able to predict the other one:

\section{Wall Street Journal \\ SOVIET ARMIES INVADE YUGOSLAVIA}

\section{Pravda (Truth) \\ YUGOSLAV PEOPLE LIQUIDATE PUPPETS OF CAPITALIST POWERS}

Similarly, we should be able to predict that what Justice $\mathrm{X}$ will view as "judicial protection of fundamental constitutional liberties" will be viewed by Justice $\mathrm{Y}$ as "federal interference with the constitutional freedom of the states to experiment in the solution of their own social problems." We should be able to understand how the simple physical fact of a man's skull colliding with a policeman's club will be reported by the New York Times, the Daily Worker, the attorney for the club, the attorney for the skull, and the various judges who will view the event at second hand. Given the report of the event recorded by any of these observation posts, and knowing the value field of the observation post, we should be able to predict the report that will be recorded by any other observation post whose value field we can identify.

That such a form of knowledge is attainable is no empty dream.

4. "Indeed, it is quite enough to know the results obtained by an observer in one CS [Coordinate System] to know those obtained by an observer in the other." EinSTEin \& INFELd, The Evolution of Physics 166 (1938).

"The general theory of relativity attempts to formulate physical laws for all CS." Id. at 249 .

5. The "world-line" of a body, in modern physics, is the series of all its locations in space-time. That the earth was between the sun and the moon on a certain day would be a point in the series that constitutes the world-line of the earth. 
Roughly, crudely, and implicitly, we all have some basis in experience for predicting and discounting the ways in which value fields affect the reporting of facts.

One of the simplest shifts of perspective is that which is formalized in grammar by the distinction between first, second, and third person. Bertrand Russell, in a radio broadcast, under the heading of "conjugation of irregular verbs," offered this illuminating example:

1. I am firm.

2. You are obstinate.

3. He is a pig-headed fool.

The New Statesman and Nation recently secured from its readers large quantities of similar conjugations, of which the following are typical:

1. I am righteously indignant.

2. You are annoyed.

3. He is making a fuss about nothing.

1. I have about me something of the subtle, haunting, mysterious fragrance of the Orient.

2. You rather overdo it, dear.

3. She stinks. ${ }^{6}$

It is unnecessary to multiply examples. The question that confronts jurisprudence is whether the practical know-how that enables an experienced judge to discount bias can be formulated and rendered more systematic and less haphazard. Can we do in law what the mathematicians and the physicists have done in their more precise domains? Before we attempt to answer that question, it may be worth our while to view this question as it reappears in two other legal disguises, as the problem of precedent and the problem of causation.

\section{The World-Line of a Precedent}

The problem of judicial precedent has been a focus of legal philosophy in America for more than a generation. Those who have criticized our courts for obstructing the paths of progress have generally suggested that the chief trouble with our judges is that they pay too much attention to precedent. Perhaps a stronger case might be made for the conclusion that judges pay too little attention to precedent and, therefore, often misread the lessons of the past. Recent studies in legal history have made this clear, I think. The courts that invalidated or emasculated almost all forms of federal social legislation between 1885 and 1935 were generally attacked by laymen as slaves of precedent. In fact, however, most of the statutes thus invalidated (e.g., those regulating wages, hours, prices, and employment contracts)

6. Quoted in Hayakawa, Language in Thought and Action 96 (1949). And see Thouless, How to Think Straight 4 (1948). 
had long and respectable genealogies reaching back into medieval and ancient law. It was the judges who (with the help of Kant and Spencer) were innovating in the cause of a new gospel of individualism and it is no accident that those judges who, like Holmes, were conservative by nature and good legal historians, refused to participate in the fifty years' massacre.

The fact is, however, that the question whether courts should follow precedent as much as they do is a wholly misleading question. Conformity to history, as Justice Holmes observed, is only a necessity and not a duty. What is true of history in general is equally true of that part of legal history that we call judicial precedent. No judge could possibly hand down a decision in any case for which a commentator could not find a precedent, even if the judge himself failed to find one. To say that a decision is unprecedented is to say either (1) that we do not agree with the use it makes of the precedents, or (2) that we do not know the precedents that might be cited in its support. Each of these statements tells us a good deal about the person who makes the statement but very little about the nature of the decision and its relation to the past. In this respect, the statement that a decision is unprecedented is very much like the statement that certain philosophical or literary works are "original"; such allegations only measure the allegator's ignorance of history. In short, the real question is not whether judges should follow precedent (or logic or the law of gravitation or anything else that they cannot help following, whether they know it or not) ${ }^{7}$ It is, rather, how they should follow precedent, that is, how they should interpret past cases and how they should draw the lines of similarity that connect past cases and present cases.

One of the unfortunate consequences of the sustained controversy over the judicial duty to follow or to ignore precedent in the interest of social welfare is the impression that following precedents is a process of logic. "Up with logic" and "Down with logic" have become the battle slogans in a controversy where logic is essentially neutral, as it is in all human controversies. Actually, logic can never establish that one case is a precedent for another case. That is because no two cases can possibly be alike in all respects. (If they were alike in all respects, then, according to the principle of the identity of indiscernibles, they would be one case, not two cases.) Any two cases, however selected, are alike in some respects. (Otherwise, they would not both be "cases.") Whether the respects in which two cases are alike are important is a question not of logic but of values. Within one framework of values, it makes no difference whether the defendant in a damage suit is a helpless widow, a powerful steel corporation, a person of Japanese ancestry during a war with Japan, a pugnacious labor

7. F. S. Cohen, The. Ethical Basis of Legal Criticism, 41 YALE L.J. 201, 219 (1931); Ethical Systems and Legal. Ideals 40 (1933). 
leader, or a government official. Under such a standard of "impartiality," the differences between the parties become irrelevancies. But to a judge who thinks that differences between defendants ought to be given weight, and to a lawyer or observer who thinks that such differences are given weight, the differences between the parties in the earlier case and the pending case may seriously change or destroy the precedent-value of the earlier case.

Consider, again, the time differential that always intervenes between the "precedent" case and the case in which it is cited. Clearly the fact that a case has been decided and reported has some social significance. Perhaps others have relied on the decision. Perhaps other courts have built on it. How they have relied on it and built on it is not a question of logic. Often the later interpretation and application of a decision are such as may shock its original author. But, for better or worse, a ten-year old decision has a weight and shape that did not exist at its birth. Its weight and shape embody all sorts of subsequent social judgments. And the world that surrounds the ten-year old offspring is an older, if not a wiser, world than that into which it was born. Contract forms, political forces, and social institutions have changed, perceptibly or imperceptibly. Here, again, logic will not suffice to determine whether a case is "on all fours" with any case decided ten years or a hundred years ago. Whether it is "on all fours" depends upon what we think of the years between and of their effect on the cases and affairs of men.

If significant differences between cases may flow even from differences in dates of decision and differences in the parties, the fact remains that further differences can always be found, as a practical matter, between any two cases. There is no precedent that cannot be distinguished away if you want to distinguish it. The use of a precedent always implies a value judgment, a judgment that similarities between the precedent and the following decision are important and that dissimilarities are relatively unimportant. The application of precedent thus always involves a process of selection or discrimination. But one man's pattern of selectivity is not the same as another man's. A judge who thinks that labor organization ought to be encouraged will rebel when decisions in antitrust cases involving capital are invoked against labor. To such a judge, the later decision may appear to force the processes of justice into a purely mechanical mold based upon a false analogy. But a judge who thinks labor organization has gone far enough or too far may view the reluctance of his brothers on the bench to decide labor cases in accordance with the usual antitrust precedents as proof of their willingness to subordinate law and logic to mere expediency or demagoguery.

According to the common view, it is logical to follow precedents but illogical to make precedents. But even a slight acquaintance with the development of modern logic makes it clear that logic is no re- 
specter of age. There is logic in change as well as in constancy, in relativities as well as in absolutes. If we give up the old exclusive reliance upon the form of the syllogism, we do not have to surrender to impressionism. The rapidly developing logic of relations and of systems, which underlies field theory, points to the possibility of a more scientific approach to judicial prediction than is offered by some contemporary mystics in the law.

Disagreeing judges and opposing counsel will regularly disagree as to whether a precedent is squarely in point, not because either side is mistaken in its logical calculations but because the two sides bring to bear upon the issue different sets of value judgments. Ordinarily these value judgments are not made explicit. To make them explicit would, as Holmes has said, deprive judges of "the illusion of certainty which makes legal reasoning seem like mathematics." ${ }^{8}$ Often the judges who make these implicit value judgments are not aware of them and would bitterly and honestly resent the imputation that they are allowing their own value judgments to enter into the decision of cases. In this respect, again, judges are like other human beings. We are none of us aware of our own prejudices: The best way to find out whether a man is prejudiced against Catholics or Jews or immigrants is not to ask him but to analyze his descriptions of events in which Catholics or Jews or immigrants appear. One of the most common manifestations of prejudice, for example, is the tendency to mention certain religions or races in describing a wrongdoer but not in describing his victim.

If we found the same events described in two newspapers in the terms given in the following columns, we should know something about the physical events but also something about the value selectivities of the reporters of the events:

1. Mr. William Bellanca, prominent airplane designer, was held up last night by an unidentified Italian gangster.

2. Three American workers were fired to make room for Jewish refugees at the hat factory in Mudville last month. 1a. Mr. William Bellanca, prominent Italian-born airplane designer, was held up last night by an unidentified gangster.

2a. Ten native townspeople were given permanent employment by a Jewish refugee in his hat factory in Mudville, and three other local residents were given temporary employment pending the arrival of members of the owner's family who have been held in concentration camps for seven years.

8. Collected Legal Papers 126 (1921). 
The selectivity operation that we execute when we hold up one decision as precedent for another decision will, in general, expand the force and scope of those decisions that we agree with; at the same time it will restrict the force and scope of decisions that we think wrong and ill-advised. In dealing with decisions that we approve of we will generally, consciously or unconsciously, stress the broad principles of justice enunciated in the case. The decisions we disapprove of we may seek to restrict to "the facts of the case as it was actually decided," which is a politely circuitous way of saying that we would not give the decision any weight at all in any later case. ${ }^{9}$ But we do not have to go so far in order to free ourselves from the incubus of an apparent precedent. We are bound to find some points of difference, which will grow in importance as we reflect on the harm that would be done by ignoring these points of difference and applying an old decision to the situation now before the court. And so we generally end up our briefs and arguments as lawyers, or our opinions as judges, with a stronger conviction of the justice of our result than we had when we started our search.

Llewellyn has written of the ways in which the precedent-value of a case increases or diminishes, of the "minimum value" and "maximum value" of a precedent, and of the techniques for "getting rid of precedents deemed troublesome . . . and making use of precedents that seem helpful." ${ }^{10}$ Oliphant has offered the analogy of an infinite pyramid in which a case may "stand for" broader or narrower principles depending upon how far up or down the ladder of abstraction we move in handling the case. ${ }^{11}$ Both these analogies are helpful, though they inevitably oversimplify the problem. What is important to recognize is that the shape of a precedent, as well as its size, will vary with the selectivity-grid through which it is viewed. One side of the precedent may grow while the opposite side shrinks. And a series of cases which looks like a straight line from one value standpoint may look like a very crooked stick from another.

If these variations in the shape and force of a precedent were completely unpredictable, law would have all the uncertainty that Jerome Frank thought it had before he became a judge. But the fact is that we do know something about the selectivity patterns of most judges which shape the line of development of any precedent. In fact a very important part of the process of selecting judges is devoted to the eliminating of judges with disrespectable or unpredictable value patterns. When we find a marked judicial shift in value judgments, as in Chief Justice Hughes' and Justice Roberts' opinions in the first Labor Board

9. Llewellyn, The Bramble Bush 63 (1930).

10. Id. at $65-6$.

11. Oliphant, A Return to Stare Decisis, 6 Am. L. School Rev. 215, 217-18 (1928). 
cases, ${ }^{12}$ we can tell that other precedents in many other fields of law will thenceforward cease to be precedents because a new value-attitude has been taken (though not expressly formulated) with respect to social legislation.

According to traditional judicial logic, every precedent moves in a straight line, imparting its direction to every case that gets in its way. In fact, however, we find that the force and direction of a precedent vary with the field in which it is observed. We are not now, and probably never will be, able to predict the path of a precedent with absolute certainty. No more can we always, with complete assurance, predict the path of a merely physical object. But at least we know that information about the weight of the object and its direction and velocity at a given point would be relevant to our prediction. So, too, we know something about the relevant factors in plotting the path of a precedent. We know that the line of motion of any precedent is subjected to a special pull that skews it whenever it passes near a point of high value tension. A series of precedents that shows a straight line when the judgments range from $\$ 1,000$ to $\$ 100,000$ may swerve pretty sharply when a case involves a twenty million dollar judgment against a government or other public institution that cannot make such a payment without serious public repercussions. Precedents that point to the protection of civil liberties may suddenly dwindle in times of public hysteria, ${ }^{13}$ but after the hysteria subsides they may resume their original force and direction.

In all this interaction of events with surrounding value fields we have the kind of problem with which field theory in physics has grappled

12. NLRB v. Jones \& Laughlin Steel Corp., 301 U.S. 1 (1937) ; Associated Press v. NLRB, 301 Č.S. 103 (1937) ; Washington V. and M. Coach Co. v. NLRB, 301 U.S. 142 (1937).

13. The attitudes towards Mormonism that prevailed in the 1880 's are attitudes that most of us can easily recognize as hysterical because we do not share them today. The Supreme Court decisions which upheld elimination of Mormons from public office, their disfranchisement, and the confiscation of Mormon Church property justified these punitive measures on the ground that certain teachings of Mormonism were a "nefarious .. . blot on our civilization . . . contrary to the spirit of Christianity." Mormon Church v. United States, 136 U.S. 1, 49 (1890). Under the impact of this attitude the Supreme Court maintained that religious freedom comprised only freedom of inner beliefs and did not extend to "practices" or "propaganda." Reynolds v. United States, 98 U.S. 145 (1878) : Davis v. Beason, 133 U.S. 333 (1890). In other words, legislation commanding religious persecution is upheld, so long as it singles out its victims by means of some observable fact in their speech, ritual, or conduct, and does not limit itself to their private and secret thoughts. F. S. Cohen, Supreme Court and Religious Liberty, 4 JEwisH Frontrer 6 (July, 1937). And note the shift between June 21, 1943 and December 18, 1944, in the Supreme Court's attitude towards legislation singling out persons of Japanese ancestry for confinement. See Hirabayashi v. United States, 320 U.S. 81 (1943); Ex parte Endo, 323 L.S. 283 (1944) ; and cf. Rostow, The Japanese American Cases-A Disaster, 54 YALE L.J. 489 (1945); F. S. Cohen, The Cicil Rights Report, 5 ETC. 161 (1948). 
for some decades. Is it not conceivable that the forms of analysis that have proved useful in the world of physics may likewise prove illuminating in the world of law?

The guiding thread in Einstein's general theory of relativity is the hypothesis "that the space-time structure, though normally flat, would become warped in the neighborhood of matter. It was this warping which was responsible for the presence of a gravitational field in the ordinary sense." ${ }^{14}$ From this assumption, physicists have derived a method of procedure:

"Thus, when we wish to determine the path and motion, say, of a planet we first determine the space-time curvature around the sun and we deduce therefrom the lay of the geodesics (straightest lines). The world line of the planet will then lie along the geodesics corresponding to the initial position and velocity of the planet." 15

The absolute space of unchanging rules and unmoving precedents that characterized traditional jurisprudence is gone. In its place we have a "life space" ${ }^{16}$ with many "value regions." Whatever passes from one region to another,- - a rule, a precedent, or a statement of facts - changes its weight, its shape, and its direction in accordance with "the lay of the geodesics" of that region. Some of these regions we are aware of; others we still need to explore.

The egocentric distortion we all recognize, at least in others. We say that no man should be a judge in his own cause. But we still allow judges to decide whether they are themselves prejudiced. And few of us have any qualms when we judge ourselves. The facts that we dislike we call theories; the theories that we cherish we call facts. And yet, because we recognize the egocentric distortion, and are able to laugh at it, and to discount it, most of us outside the asylums manage to live in a world that is not purely private. In fact, the small-scale distortions that center about the life space of each individual tend to cancel each other in any long-range movement. They are thus less serious, from the standpoint of the legal order, than the group distortions, ethnic, national, and economic, which reinforce each other and thus powerfully affect all large-scale movements in the social world.

Large-scale social facts cannot be explained in terms of the atomic idiosyncrasies and personal prejudices of individuals. Lines of precedent are large-scale social facts involving large numbers of individual judges and litigants. That is why the "belly-ache" theory of judicial decisions can never explain how any rule of law comes into being or changes in time. And that is why a realistic view of the role of precedents requires an exploration of group-reenforced value patterns. Such

14. D'Abrot, The Decline of Mechanism in Modern Physics 81 (1939).

15. Id. at 85 .

16. Cf. K. Lewin, Principles of Topological Psychology (1936). 
an exploration might explain many facts on which the ceremonial rules of traditional jurisprudence throw no light,--for example the fact that the judges appointed by a given administration uphold the validity of the activity of that administration in not less than ninety-six per cent of the cases in which it is challenged. So, too, such an exploration might indicate how it happens that when anybody enters the life space of a public office, bringing to it a certain momentum and energy, the life space of the office will impose its goedesics upon him: he will ask for more appropriations, seek increased power for his office, adopt certain protective attitudes towards his assistants. At the same time, those directions of his activity that are peculiar to himself are likely to cancel out against the opposing directions of his successors, colleagues, and predecessors in office. Just so, the man who dons the judicial robe with the greatest contempt for precedent finds that the pressure of his office-space compels him to follow paths that, from outside the office-space, once appeared absurd.

It would be tedious to multiply examples of the ways in which unavowed value patterns - particularly group value patterns-direct the flow of events in the space we call law. It is enough to see that we can reject the old idea of straight lines of precedent filling absolute legal space, without surrendering to chaos or impressionism. Relativity also has its laws, its certainties, and its demanding quests for verifiable fact.

\section{Causation: Physics and Practical Politics}

Some form of causation is involved in every law suit. For every plaintiff claims that somehow the defendant has caused him to suffer and for that reason should be subjected to the strong arm of the law. One might expect, therefore, that after so many centuries of litigation jurists would have a pretty clear idea of what causation really is. The fact remains, however, that jurists have ordinarily conceived of "causation" as a problem of natural science and have therefore studiously refrained from inquiry as to its significance.

On the other hand, natural scientists have decided in recent years that causation has no proper place in their studies, that in fact "cause," its Latin progenitor "causa," and its Greek prototype airia, are all words borrowed from the law courts, which crept into physics on the coat tails of the dignified Stoic theory that the physical world is run like a legal system, under "laws of nature." 17 Today physicists are pretty generally agreed in rejecting as invalid the explanation that gravitation is the "cause" of an apple's downfalling. Gravitation is nothing but a highly abstract way of stating the fact that apples and many other things do fall. Insofar as the idea of "cause" carries with

17. See M. R. Cohen, The Meaning of Human History 95 (1947). 99 (1928). 
it an anthropomorphic or animistic sense of pushing and pulling, it has no proper place in modern physics. Functions and equations have displaced "cause and effect" as the basic terms of physical explanation. The trend of scientific physics is being reflected today, more or less promptly, in every other science.

Where does this leave the jurist? If "cause" is banished from law, will lawsuits be banished also? Or can we refine the concept of causation and hold on to it in the law even though all other sciences reject it?

According to the orthodox view, whether event $A$ is the cause of event $B$ is a question of objective fact to which all value judgments are irrelevant. What, then, we may ask, is the cause of the injury when a plaintiff and his car have been smashed up by defendant's car? The location and speed of the defendant's car certainly contributed to the accident. So, too, did the location and speed of the plaintiff's car; if plaintiff had stayed in bed instead of driving, he would not have been hurt. Relevant also are the durability and tensile strength of the two cars, the width of the road, the character of the road-surface, the weather, and a host of other more or less important facts. How can we possibly pick out one of these facts, or any combination of them, and say: "This was the cause of the accident?" Certainly there is no rule of physics, no rule of engineering, and no rule of logic that will enable us to reach such a result.

What do we actually do? If it turns out that plaintiff was driving on the right side of the road and that the defendant was driving on the left side of the road, we say that the defendant's driving on the left side was the cause of the accident, unless the case arises in England, in which case we say that the plaintiff's driving on the right side was the cause of the accident. From the standpoint of logic or physics the physical collision of the cars had exactly the same physical antecedents whether the collision occurred in England or in America. But from the standpoint of the law, the judgment of "wrongness" or "carelessness" is an essential part of the judgment that attributes the cause of the accident to some human act. Without such standards, we should find in every accident only the intersection of an infinity of strands of occurrences reaching back into the past without end.

What we actually do when we look for a legal cause is to pick out of this infinity of intersecting strands a useful point at which public pressure can be placed. ${ }^{18}$ We pick one point rather than another because we think the imposition of pressure at that point will tend to bring about either a better course of conduct on the part of defendants or a

18. "A cause, but not the proximate cause. What we do mean by the word 'proximate' is, that because of convenience, of public policy, of a rough sense of justice, the law arbitrarily declines to trace a series of events beyond a certain point. This is not logic. It is practical politics." Andrews, J., dissenting in Palsgraf v. Long Island R.R., 248 N.Y. 339, 162 N.E. 99 (1928). 
fair measure of relief for plaintiffs. What we will take to be the cause of an accident, then, is not determined entirely by the objective facts. The standards of conduct applied to the situation are an integral part of any judgment of legal causation.

In this, the law does not differ essentially from other social fields. When one man finds the cause of high prices in high profits, another in high wages, and a third in high taxes, we recognize that three different value patterns are being applied to the same set of facts. That, perhaps, is why statistical facts and figures seldom sway anybody's viewpoint in such a controversy. When we meet a man who feels that all his efforts are constantly being thwarted by the connivings and conspiracies of other people, we recognize that such a person's ascriptions of causal efficacy may be powerfully affected by a private system of values. If he tells us that all his failures are the result of Catholic conspiracies, or a conspiracy of publishers not to publish his works, we learn a little more about his own set of value judgments, even though we may learn very little about Catholics or publishers. So, too, if a writer tells us in May of 1941 that the cause of World War II is British imperialism and tells us, a few weeks later, that the cause of World War II is Nazi aggression, we may not learn much about World War II, but we do learn something about the "line" of our writer. Indeed we generally learn a good deal more about other peoples' value standards from the statements they make about causal relations than we do from their explicit formulations of value standards. The acquisition of similar knowledge about our own unavowed value standards is a more painful process. ${ }^{19}$

The intimate dependence of causality judgments upon value standards is evident in the work of those historians whose value judgments differ from our own. As Morris R. Cohen points out in The Meaning of Human History,

"In effect [most historians] select from the vast conglomerate of determinants which form the necessary and sufficient conditions of a given event some element or elements to which they attach special importance and this they call 'the cause,' classifying all other elements as "conditions.'"

"Now, though it is perhaps inevitable that historians, like other human beings, should see causal relationships through a screen of human values that gives importance to some antecedents and rele-

19. "We may often find it easy to indicate approximately on what properties of an object our liking or disliking is founded. But we do not realize with the same clearness on what characteristics of our own self these attitudes depend. For this reason it is, and often remains, so difficult to understand certain valuations of others, for example in the field of art or in that of sex." Kohler, The Place of Value in a World of Facts 339 (1938). 
gates others to obscurity, it is not inevitable that historians should fail to recognize that this is what they are doing. Indeed if the role which value judgments play in determining our opinions as to historical causation were more clearly understood, we should have less difficulty in understanding how historians who agree on measurable facts so of ten disagree in tracing the causal relations between them; how, for instance, the decline of Rome can be attributed by equally conscientious and intelligent historians working from a common fund of historical data to such diverse factors as the exhaustion of soil, the corruption of rulers, the rise of Christianity, spots on the sun, and population movements in central Asia. At the same time we might be more cautiously skeptical of the moral lessons drawn from history by historians who fail to disclose the moral presuppositions with which they embarked on the task of historical explanation. For few historians have recognized, as did Darwin, that facts which do not fit into our theories make less of an impression on us than those that do, or have made a sustained effort, as Darwin did, to give special note to those facts that fail to fit into preconceived patterns. Indeed the field of history is so much more complex than that of biology that it is doubtful whether any efforts to make allowances for our own value systems in the writing of history can ever be completely successful. But the historian can make a contribution to intelligent understanding and to the scientific objectivity that transcends national boundaries, racial loyalties, and class interests, by setting forth, as a good map-maker does, his own magnetic deviations and perspectives." 20

That judgments of causality vary with the standpoint of the observer has come to be widely recognized during recent decades, in scientific, legal, and philosophical circles. ${ }^{21}$ Consider, for example, the

20. M. R. Cohen, The Meaning of Human History 113-15 (1947).

21. "Thus the cause of death, for example, will depend upon the principle of selection employed by the reporter. It will be moral or legal for one observer, physiologic for another. And even to the physician the cause will be heart failure, local infection, or some other pathological condition, according to his point of view. Thus certain causes appear more often at certain times than at others. Greater attention, for example, is now paid to heart disease, and peritonitis almost disappears because of the appearance of appendicitis. So, likewise, if a glass breaks when it falls, I can say that it breaks because it was dropped, or because it is made of brittle material, or because it slipped from my nervous hand. But any one of these conditions is part of a system or perspective. In each perspective the relation is determinate." M. R. Cohen, The Meaning of Human History 96-7 (1947).

And see R. B. Haldane, The Reign of Relativity 121-2 (1921):

"Cause is a very indefinite expression. Externality to the effect is of its essence, but its meaning is relative in all cases to the subject-matter. For the housemaid the cause of the fire is the match she lights and applies. For the physicist the cause of the fire is the conversion of potential into kinetic energy, through the combination of carbon atoms with those of oxygen and the formation of oxides in the shape of gases which become progressively oxidized. For the judge who is trying a case of arson it is the wicked action of the prisoner in the dock. In each case there is a dif- 
very practical question: What is the cause of malaria? In the history of science, various answers have been given to this question:

"The ancients found a correlation between exposure to damp air, especially at night, and malaria. It was an essential task of biology and medical science to ask why these two should be thus connected. An intermediate term was found in the bite of certain mosquitoes. But why should the bite of the mosquito produce the given result? Again an intermediate term is found in the virus that is injected into the organism by the bite. But why should that virus destroy the red blood corpuscles? It is obvious that no matter how many middle terms are thus interpolated we still have a discrete series, and the question why two terms should be causally connected remains. This is, of course, no objection to a process which extends our knowledge even though it never can be absolutely completed." 22

Clearly, for the sanitary engineer, the existence of untreated swamps is the cause of malaria. For the king's attendant with the palm-leaf fans, the bite of the mosquito is the only relevant cause. For the pathologist, the effect of the malaria virus upon red blood corpuscles is the cause. In each case the cause is the point at which effort can be usefully applied.

At least two great American judges, Benjamin Cardozo and Henry Edgerton, have clearly recognized that in law, as elsewhere, judgments of causation are essentially relative and purposive. Thus Justice Cardozo, after noting the infinity of antecedents that come together in any event we seek to ex plain, observes:

"From this complex web the law picks out now this cause and now that one. Thus the same event may have one jural cause when it is considered as giving rise to a cause of action upon contract, and another when it is considered as giving rise to a cause of action for a tort. The law accepts or rejects one or another as it measures its own ends and the social benefits or evils of rejection or acceptance.

"A case will point my meaning. A fire occurred at Big Tom, New Jersey. The fire exploded dynamite. The explosion by its vibrations caused damage to a vessel standing out in the river half a mile away. A policy of insurance secured the owner of the vessel against loss proximately caused by fire. The court assumed that by the law in most jurisdictions the fire would be the jural cause if the action were in tort against a wrongdoer who had negligently spread the flames. Indisputably it would if he had acted with intent to

ferent field of inquiry, determined from a different standpoint. But no such field is even approximately exhaustive. . . Thus we see that when we speak of the cause of an event we are only picking out what is relevant to the standpoint of a special inquiry, and is determined in its scope by the particular concept which our purpose makes us have in view."

22. M. R. Cohen, The Meaning of Human History 105-6 (1947). 
cause the very damage that resulted. On the other hand, the court refused to find that the fire was the jural cause within the meaning of the contract.

"The reasoning that led to this conclusion is in close approach to Lord Haldane's, though rendition of the judgment preceded by some years the publication of his book. 'In last analysis,' we said, 'it is something in the minds of men, in the will of the contracting parties, and not merely in the physical bond of union between events, which solves, at least for the jurist, this problem of causation. In all this, there is nothing anomalous. Everything in nature is cause and effect by turns. For the physicist, one thing is the cause; for the jurist, another. Even for the jurist, the same cause is alternately proximate and remote as the parties choose to view it. A policy provides that the insurer shall not be liable for damage caused by the explosion of a boiler. The explosion causes a fire. If it were not for the exception in the policy, the fire would be the proximate cause of the loss and the explosion the remote one. By force of the contract, the explosion becomes proximate. A collision occurs at sea and fire supervenes. The fire may be the proximate cause and the collision the remote one for the purpose of an action on the policy. The collision remains proximate for the purpose of suit against the colliding vessel. There is nothing absolute in the legal estimate of causation. Proximity and remoteness are relative and changing concepts." "23

Probably the most precise formulation of the value-orientation that is implicit in every judgment of causation is that given by Judge Edgerton in his epochal article on "Legal Cause." 24 The painstaking analysis of cases and materials in that article exposes the emptiness of all efforts to define "cause" or "proximate cause" in terms simply of time, space, and mechanics and without reference to values. Judge Edgerton's thesis is best summarized in his own words:

"A wrongful act or omission has occurred, a harm has been suffered. Will the law treat the one as the cause of the other? My thesis is that it neither is nor should be possible to extract from the cases rules which cover the subject and are definite enough to solve cases; that the solution of cases depends upon a balancing of considerations which tend to show that it is, or is not, reasonable or just to treat the act as the cause of the harm - that is, upon a balancing of conflicting interests, individual and social; that these considerations are indefinite in number and value, and incommensurable; that legal cause is justly attachable cause. I believe that, while logic is useful in the premises it is inadequate; that intuition is necessary and certainty impossible.

23. Cardozo, Paradoxes of Legal Science 83-5 (1928).

24. 72 U. of PA. L. Rev. 211, 343 (1924). 
"The fact that the rules of legal cause are intended to produce a just result, rather than to save time or avoid uncertainty, is emphasized by the attitude of the law towards what may be called alternative causes; i.e., causes each of which, without the concurrence of the other, would have been sufficient to produce the result. In general, 'a defendant's tort cannot be considered a legal cause of plaintiff's damage, if that damage would have occurred just the same even though the defendant's tort had not been committed.' [1]

"But, by exception 'where two tort-feasors are simultaneously operating independently of each other, and the separate tortious act of each is sufficient in and of itself to produce the damaging result,' each is liable. $\left[{ }^{2}\right]$ It would be shocking to our sense of justice to relieve two wrongdoers of liability on the ground that both are responsible."

Today it is perhaps no longer necessary to argue that judgments of causation in the law are relative and changing. The real question is how they change. Can we plot out the ways in which changing judgments of purpose and value will lead courts to shift the directions in which they seek to trace chains of causation?

It is when we face the problem of how judgments of causality vary that the physical analogy of a field of forces becomes helpful. Such an analogy may indicate that just as precedents shift in direction when they enter a neighborhood of high value tension, so judgments of causality will undergo a similar shift in direction. Generally, the direction shift, whether of precedent connection or of causal connection, will be such as strengthens and reinforces the basic valuations in the field. Precedents which support our objectives grow; precedents that appear to others to be against us drop away. Causal connections which support our objectives are strengthened; those that threaten them drop away. Thus, increasing sympathy for the victims of industrial accidents will bring about a broadening of the field within which causation for such accidents is found in some act of an employer who is able to provide some measure of compensation. ${ }^{25}$ Similarly, increasing fear of Communism (or, in a Communist society, of anti-Communism) will expand the field in which responsibility for industrial stoppages and breakdowns is ascribed to Communist (or anti-Communist) propaganda.

All of us, in everyday life, when we attribute causality to anybody or anything, do so through a highly selective value-screen. Most of us, for example, in thinking about accomplishments of which we are

[1]. Smith, Legal Cause in Actions of Tort, 25 HARv. L. REv. 303, 312 (1912).

[2]. Ibid.

25. See Charmont, Les Transformations du Droit Civil, c. 15 (1912). 
particularly proud, attribute the cause of our success to our foresight, perseverance, hard work, or other admirable qualities. Even if we are too modest to talk aloud in these terms, these are the terms in which we generally think. On the other hand, in thinking about our failures, we commonly find that they were brought about by some action of third parties, some accident of the weather, or something else external to ourselves. When we view the works of others, we are more likely to attribute their successes to external circumstances such as inherited wealth, parental care, educational opportunities, and good fortune in health, unless those we are judging are persons whom we particularly love or respect. So, too, we are more skeptical towards others than we are towards ourselves or our dear friends when it comes to excusing failures and misdeeds by attributing them to the intervention of external causes. Concisely, we may say that "causality" is a valueweighted term. The person we admire is viewed as active in the events we admire and as external or passive in events we condemn, which are then viewed as the product of external circumstance. With persons we despise or hate, success is normally attributed to environmental factors for which they can claim no credit, and failure is traced to the person judged. ${ }^{26}$

The skewing of causal judgments by high-value and low-value orientations is particularly noticeable in a society with value standards radically different from our own. For example, Communist Russians will attribute all the great achievements of the United States to facts for which its citizens are not responsible, e.g., supposedly unparalleled natural resources, separation by oceans from powerful neighbors, the contributions of Europe in man-power and idea-power, the role of Russian battleships in preserving the Union and the role of Russian armies in saving America from German invasion in the first and second World Wars. On the other hand, those aspects of American life which may be held up to international contempt (e.g., lynching, racial segregation, or backwardness in music or chess) are never linked with external causal factors but always attributed to the inherent vices of the American way of life. In our own judgments of ourselves an opposite skewing may be observed by any impartial observer.

When two people in a law court blame each other for an accident they are simply behaving like human beings. The function of a law court is not to eliminate all the personal value-tones that lead individuals to draw causal lines one way or another but rather to apply a more comprehensive set of values and to achieve a more comprehensive view of the facts as a guide for social action.

26. The shifting lines we draw between an individual and his environment mark the outlines of the problem of civil and criminal responsibility. See F. S. Cohen, The Socialization of Morality in Kallen \& Hook, American Philosophy Today and TomorRow (1935). 
From this analysis a number of inferences can be drawn concerning the disposition of actual cases, and by testing such inferences against the facts we can hope to illumine the validity of this analysis. Such a task must lie beyond the limits of the present essay. But perhaps it is significant to formulate the following hypotheses:

1. The more reprehensible the conduct, the more readily will judges find a causal connection between the conduct and the injury complained of. ${ }^{27}$

2. The more hateful the defendant, the more readily will judges find a causal connection between the defendant and the injury complained of. ${ }^{28}$

3. A judgment against a highly respected citizen has a larger precedent value than a judgment against a despised person; conversely, a judgment in favor of a despised person has a larger precedent value than one for a pillar of society. ${ }^{29}$

4. A value differential in attitude of judge and jury towards a given class will be reflected in differences of judgment as to whether individuals of the given class are responsible for the wrongs complained of.$^{30}$

\section{Public Policy: A Field Theory of Values}

Public Policy vs. The Law

"Public policy" has been traditionally viewed as an emergency factor upon which an attorney may call when the cases and statutes are against him, and to which a judge may look when the law has been

27. Compare Bacon's statement of the point:

"'In jure non remota causa, sed proxima spectatur.' It were infinite for the law to judge the causes of causes, and their impulsions one of another; therefore it contenteth itself with the immediate cause, and judgeth of acts by that, without looking to any further degree.... This rule faileth in covinous acts, which though they be conveyed through many degrees and reaches, yet the law taketh heed to the corrupt beginning, and counteth all as one entire act. . . . In like manner, this rule holdeth not in criminal acts, except they have a full interruption; because when the intention is matter of substance and that which the law doth principally behold, there the first motive will be principally regarded, and not the last impulsion." BAcoN, MAXims of The LAw, Regula. I.

28. Consider the probability of securing a fair trial of a murder charge against foreign-born anarchist workers by a judge who refers to the defendants before him as "those anarchistic bastards". See Fraenkel, The Sacco-Vanzetri Case 542 (1931).

29. "[O]ur democracy entrusts the task of maintaining its most precious liberties to thase who are despised and oppressed by their fellow men." F. S. Cohen, Indian Rights and the Federal Courts, 24 Minn. L. REv. 145, 200 (1940).

30. Consider, for example, the repeated decisions of juries that the famous financier Russell Sage was partly responsible for injury to a visitor whom he used as a shield against a bomb, which decisions were repeatedly set aside by judges who could see no connection between the financier's conduct and the injury to his visitor. Laidlaw v. Sage, 158 N.Y. 73, 52 N.E. 679 (1899). 
rendered sufficiently unclear by advice of counsel. On the basis of such a view of "public policy" a spirited controversy has raged for many decades over the issue whether "public policy" is a proper ground for striking down a rule of law or a line of precedents. ${ }^{31}$ But in reality the issue between law and public policy is chiefly rhetorical. Every rule of law, every interpretation of a statute, every standard of what a "reasonable man" would do or say or believe or approve, every line of precedents, every view of what any decided case "stands for," always presupposes one view or another as to "public policy."

What facts in a case are important when the case is being decided, and what facts are important after the case has been decided and when it is cited as a precedent, these are questions that cannot be answered without criteria of importance. And every judgment of importance implies a judgment of value or public policy. Without judgments of public policy there can be no rules, no precedents, but only endless, fathomless, systemless, collections of individual cases, each case sufficient to itself and bearing no important resemblance to any other case.

Of course, most judges, like most human beings, see their own views of public policy not as policy views but as eternal truth, the spirit of the common law, the basic principles of Anglo-American liberty, or, more simply, as the law. We see other people's eyes; but we never see our own. We see other people's prejudices; our own prejudices we view as the teachings of experience. If we ever come to see our own views as prejudices, they have, by that token, ceased to be prejudices and have become hypotheses to be examined and confirmed or rejected. So it is with metaphysics. Judges and non-judges who denounce metaphysics do not thereby escape from metaphysics. Nor do they establish the truth of their own metaphysical assumptions. All they establish is their unawareness of their own basic assumptions.

There is a special reason why most judges will not willingly uncover, even in the privacy of judicial chambers, their basic valuations. For the custom of the realm and the defense of the status quo require that judges should appear to be unsusceptible to the wayward gusts of human emotion. The law is supposed to be objective, impersonal, and firmly grounded in the indubitable. On the other hand, everybody knows - especially judges and lawyers and law professors - that men's views of what is good and bad vary atrociously from place to place and from year to year. And so, as Holmes told us many years ago,

"Perhaps one of the reasons why judges do not like to discuss questions of policy, or to put a decision in terms upon their views as lawmakers, is that the moment you leave the path of merely logical deduction you lose the illusion of certainty which makes legal

31. An excellent analysis of this controversy is given in Stone, The Province and Function of LAw 494-504 (1946). 
reasoning seem like mathematics. But the certainty is only an illusion, nevertheless." 32

"The very considerations which judges most rarely mention, and always with an apology, are the secret root from which the law draws all the juices of life. I mean, of course, consideration of what is expedient in the community concerned. Every important principle which is developed by litigation is in fact and at bottom the result of more or less definitely understood views of public policy; most generally, to be sure, under our practice and traditions, the unconscious result of instinctive preferences and inarticulate convictions, but none the less traceable to views of public policy in the last analysis." 33

"I think that the judges themselves have failed adequately to recognize their duty of weighing considerations of social advantage. The duty is inevitable, and the result of the of ten proclaimed judicial aversion to deal with such considerations is simply to leave the very ground and foundation of judgments inarticulate and of ten unconscious." 34

Perhaps the judicial blindness that Holmes criticized is really protective. Perhaps value judgments which are inarticulate and unconscious are less easily criticized than those which are frankly avowed. If this be so, then it will be necessary for those who seek to achieve a critical and comprehensive view of the law in action to ferret out the judicial value patterns that underlie decisions.

In that task it is not enough to classify cases. There are always an infinite number of ways in which any pile of decisions may be classified. Psychoanalysis has not yet produced any useful techniques for predicting judicial decisions. The "breakfast theory" of judicial behavior advanced by Beccaria almost two hundred years ago as a reason for reducing the realm of unbounded judicial discretion, ${ }^{35}$ has not yet revealed any correlation between bananas or dyspepsia and the law of sales. This far, however, we have advanced. The old slot-machine or phonograph theory of the judicial role is dead. No thoughtful student of the law today denies the role that is played in the judicial process by judicial value standards. Not for a good many years has the American public accepted a "leader of the bar" as a justice of its Supreme Court. Public scrutiny of the social views of each nominee to that court has become the rule, and the rule is likely to be extended to all

32. Privilege, Malice and Intent, 8 Harv. L. Rev. 1, 7 (1894); Collected Legal PAPERS 126 (1921).

33. The Common Law 35-6 (1881).

34. The Path of the Law, 10 Harv. L. Rev. 457, 467 (1897); Collected Legal PAPERS 184 (1921).

35. Beccaria, Essay on Crimes and Punishment, c. 4 (1764). 
of our high courts. It is desirable that the methods by which the value standards of a judge are scrutinized shall become more scientific.

A scientific approach to the analysis of judicial value patterns requires, in the first place, that we distinguish between pure judgments of value and mixed judgments of value and fact. Pure value judgments, e.g., that happiness is an intrinsic good, represent a highly abstract form of thought. We may find such judgments in text-books of ethics; almost never do we find them explicitly set forth in a judicial opinion. To find a judge's value patterns by looking for his explicit judgments of intrinsic value is therefore a hopeless quest.

Ordinarily, value judgments are implicit in opinions which include many elements that are not at all dependent upon our ethical views. If we think that democracy is preferable to despotism, it is because we think that democracy has certain implications and consequences which make for a better level of human life than is consistent with despotism. But whether any specific consequences actually flow from a democratic order is a question of historic fact on which it is possible to gather evidence that does not depend upon our wishes. This does not mean that historical analysis will ever prove the value of any form of government. But it may clarify the complex to which we apply a value judgment.

So, too, when we characterize the behavior of an individual as brave or rash, discreet or cowardly, heroic or quixotic, generous or foolish, persistent or pig-headed, we have imported into a psychological analysis of human conduct elements of moral valuation.

These value elements can be identified and analyzed only if we adopt an operational view of valuation. In such a view, the meaning of a value standard is to be found in its actual and possible applications. Towards such a view of values the field theory of modern physics provides an illuminating analogy and guide. Concretely, we can expect to find the value standards of a judge in his reactions to day-to-day problems of statutory construction, the weight of precedents, standards of "reasonable care" or "due process," and causation. We find the value patterns of a judge, as of any other human being, in the choices he makes between competing interpretations of fact, in the selection of value-charged words to describe given facts, and in the implicit and inarticulate premises of his arguments.

\section{The Inarticulate Moral Premise}

Every judicial opinion is, in some sense, an effort to defend or justify some decision, actual or possible. The conclusion that a certain decision is right can only follow from an argument if the argument includes one or more premises as to what is right or wrong. For reasons often noted, judges commonly do not make such premises explicit. 
Nevertheless a logical analysis of any judicial argument can generally uncover the suppressed premises.

Take, for example, the decisions of the United States Supreme Court in United States v. Joseph, ${ }^{36}$ and in United States v. Sandoval. ${ }^{37}$ Both cases involved the question whether the people of the Rio Grande Pueblos were or were not Indians. In the former case, the Supreme Court noted that "Integrity and virtue among them is fostered and encouraged. . . . In short, they are a peaceable, industrious, intelligent, honest, and virtuous people." The Court concluded that these people were not Indians, and therefore not entitled to the protection of federal laws prohibiting trespass upon Indian lands. In the Sandoval case, the Court accepted evidence supplied by the Bureau of Indian Affairs to the effect that the Pueblos indulged in "a ribald system of debauchery," "cruel and inhuman punishment" and "immorality and a general laxness in regard to their family relations." From these and other similar characterizations the Supreme Court concluded that the Pueblo villages are really Indian communities after all and that its earlier decision in the Joseph case was erroneous. The moral premise underlying both decisions is obvious but, for reasons of politeness or otherwise, it was left unexpressed: "Intelligent, honest, and virtuous people" cannot be Indians, but debauchery, cruelty, inhumanity, and immorality are prima facie evidence of Indianhood.

\section{Word Selection as an Index of Value Judgments}

All of us, when we communicate with our fellow human beings, are continually faced with the necessity of choosing between words similar in import but dissimilar in value tone. Shall we, for example, refer to the Secretary of Agriculture as a statesman, a politician, or a bureaucrat? Each of these terms may refer to exactly the same activities, and so the choice of one term over the others does not affect the informative value of what we say. Nevertheless, the choice embodies a value attitude. If the person to whom we are speaking is sympathetic and receptive, we may convey our attitude to him without his knowing how it has been conveyed. On the other hand, if the person to whom we are talking is alerted to the human significance of word-selection, he may learn much more about the speaker than he learns about the subject of his speech.

Whether a man speaks of "colored folk" or "Negroes" or "niggers," of "Japanese" or "Japs," of "men and women of Jewish descent" or "Jews" or "- - Kikes," does not alter the factual content of his communication, but all who are sensitive to such choices recognize the value standards that lie behind them,- even when the speaker himself

36. 94 U.S. 614 (1876).

37. 231 U.S. 28 (1913). 
does not. ${ }^{38}$ Here, then, is a ready indicator of value judgments which should be as applicable to judges as to any other human beings.

Cases involving race-value judgments or class-value judgments are particularly rich in such unconscious indications of judicial valueattitudes. Thus, for example, the pattern of race-values to which the Joseph and Sandoval cases point is strongly confirmed by the wordselections in statutes and judicial opinions dealing with Indian rights. In many cases, for example, the courts will apply to Indians terms that are ordinarily applied to animals, thus conveying the impression that the relation of an Indian to his land is similar to that of an animal to its habitat and therefore not a subject of enforceable rights. Thus, while a white man "travels" or "commutes," an Indian (like a buffalo) "roams." A white man may be of "mixed ancestry," an Indian (or a cow) is a "mixed breed." Land held by a group of white men in accordance with an intricate apportionment of individual rights is called "corporate" or "partnership" or "family" property; land held by a group of Indians under arrangements of equal or greater intricacy is dubbed "communally occupied."

This system of double talk has become standard patter for all current legislative or judicial programs designed to separate the Indian from his property. Thus, land from which Indians are excluded is "owned" by whites; land from which whites are excluded is "monopolized" by Indians. ${ }^{39}$ Governmental taking of land from white men is called "expropriation"; taking of land from Indians is called "freeing the Indian from the reservation" or "abolishing the reservation system." 40 If a government repudiates its obligations to a white man we speak of "governmental bankruptcy"; if a government repudiates its obligations to an Indian, this is commonly referred to as "emancipating the Indian." 41

The greater the value-intensities in a given field the more marked are the manifestations of such double talk. Today the Communist

38. See Thouless, How to Think Straight 3-19 (1948); Hayakawa, Language in Thought ANd Action 42-51, 84-92 (1949).

39. See, for example, the opinion of the Court of Appeals for the Ninth Circuit in Hynes v. Grimes Packing Co., 165 F.2d 323, rev'd, 337 U.S. 86 (1949), and note the cumulative effect of using the term "monopoly" or "communal monopoly" twenty-two times in describing the claim of an Aleutian Village to municipal ownership of a harbor area that included traditional fishing grounds. In sustaining the attack of the Alaska Salmon Industry, Inc., against the native community's claim, the Court of Appeals noted that the Alaska Salmon Industry, Inc., had investments of "upwards of seventy million dollars" which were largely dependent upon the packers' continued use of the area claimed by the native municipality, and also noted that the native community included only fifty-seven fishermen.

40. See the speech of Senator Butler in 95 Cong. REC. 14390 (1949) in support of his bill to "emancipate" Indians from their reserved lands, tax exemptions, and other treaty rights.

41. Ibid. 
movement probably offers the finest examples of political double-talk with rapid shifts from up-talk to down-talk, or vice versa, in accordance with the changing exigencies of politics. Western statesmen and judges, however, are not without skill in this domain. ${ }^{42}$ For example, it is interesting to note how consistently our judges are able to maintain the principle that equity will not enjoin a libel. All that is needed is a second vocabulary with which to describe those libels that courts wish to enjoin. Thus if courts want to enjoin labor unions from publishing disparaging remarks about employers they will refer to such publications not as "libels" but rather as "conspiracies" or "boycotts." ${ }^{43}$ Such verbal operations reveal value judgments of which the judges themselves are often quite unaware.

\section{Towards a Field Theory of Value}

The course of our inquiry to this point may be briefly summarized. In the suppressed moral premises of judicial opinions, in the choices between words of different value tones, in the selection, classification and interpretation of facts and precedents, and in the tracing of lines of causation, we find prime indicators of the value patterns of a judge, a judiciary, or a society. The sum of such indicators defines a value field. The definition of a value field makes the contents of the field exportable. That is to say, if we understand a proposition in the context of its own field we can translate the proposition into language that will convey the same informational content in any other value field we understand.

All this is perhaps merely making explicit and formal what most experienced judges and many lawyers know as a matter of "hunch" or "intuition," as Underhill Moore pointed out some eighteen years ago. ${ }^{44}$ Yet it seems to me that there is some value in refining such "hunches" and "intuitions" in the light of the achievements of the more advanced sciences ${ }^{45}$ Just as the physicist's idea of the uniformity of

42. Cf. F. S. Cohen, Colonialism: A Realistic Approach, 55 Ethics 167 (1945).

43. See Note, The Privilege to Disparage a Non-Competing Business, 30 CoL. L. REv. 510 (1930).

44. In the traditional jurisprudence, Underhill Moore pointed out, "the art or science of judicial behavior is a field of knowledge complete and self-sufficient, wholly independent of all others and coordinate with them. . . Such is the lawyer's traditional way of thinking of his problems, his data and his methods. To be sure it is grossly inadequate and filled with misleading notions. But for him it is a by-product of his professional work, seriously regarded on ceremonial occasions only, and never permitted to limit his field of vision to less than the whole situation upon which he gives an intuitional judgment. However, to the lawyer's rational account can be attributed his failure to recognize and his judgments are intuitional and given in inclusive situations of many biological and cultural factors, his failure even to begin systematically to take into account the factors in the situation." Moore \& Sussman, The Lawyer's Law, 41 YALE L.J. 566, 569-70 (1932).

45. Again, I find instruction in Underhill Moore's protest against the old isolation- 
nature influenced the development of Roman and international law, just as the evolutionary ideas of Kant, Hegel, Darwin, and Spencer powerfully moulded the Anglo-American law of the last century, so the developing central concept of modern physics is likely to influence the legal and ethical thoughts of the next century. Let it not be thought that the sketchy suggestions here made towards the application of the field concept to legal and ethical problems are intended as a call for a new school of jurisprudence. There have been too many such calls already. Rather does the field concept, which recognizes the limited and relative validity of many apparently conflicting views in the practical struggles of the law court and the market-place, point to the possibility that many conflicting schools of jurisprudence may all be true and valid in differing and limited perspectives or regions. But this possibility, though often suggested, ${ }^{46}$ is still sufficiently alien to the temper of contemporary controversy to deserve a few words of explanation.

\section{Through The Blind Alleys of Jurisprudence}

\section{The Elephant and the Judicial Problem.}

The six blind men of Hindustan who went to see the elephant and, in the manner of the House of Lords, delivered six separate opinions on the beast, reported respectively (according to the poetic fable) that the elephant was something like a wall, a spear, a snake, a tree, a fan, and a rope. In much the same fashion a careful historian of legal philosophy, having completed his researches into the juridical reflections of thirteen philosophers, and having "put aside immediately the attractive thought that the fundamental truths of the various phil-

ism of the law school: "The lawyer's process of institutional judgment is obviously a very rough and haphazard approximation of a precise method derived from the procedure which has been abstracted and his forecast a rough approximation of the result which would be obtained by a special application of that method. . . . One who attempts to approach precise method in forecasting the form of judicial behavior must seek the aid of workers in many other fields of knowledge. Were he to attempt to forecast the behavior of an individual in a situation which includes statutes and decisions this would be equally true. The events in the situation which he selects and takes into account include events which are the focus of study in anthropology, anthropogeography, sociology, and psychology, psychiatry and perhaps other biological sciences. In dealing with each of the selected events, he must call upon those trained in the discipline which focuses upon that particular event for the special knowledge and techniques which they command. In the application of his method he must rely upon the statistician." Id. at 574-6.

46. I have made the suggestion myself often enough. See Transcendental Nonsense and the Functional Approach, 35 CoL. L. Rev. 809 (1935) ; The Problems of a Functional Jurisprudence, 1 MoD. L. REv. 5 (1937); The Relativity of Philosophical Systems and the Method of Systematic Relativism, 36 J. OF PhILosophy 57 (1939); Review of Cairns, Legal Philosophy from Hegel to Plato, $10 \mathrm{~J}$. of the History of Ideas 575 (1949). And see M. R. Cohen, On Absolutisms in Legal Thought, 84 U. of PA. L. Rev. 681 (1936). 
osophies of law should be sifted out and then combined into one harmonious whole," gives us the dreary and orthodox picture of thirteen great legal philosophers who could not agree even on what it was they were all talking about :

"We have been told by Plato that law is a form of social control, an instrument of the good life, the way to the discovery of reality, the true reality of the social structure; by Aristotle that it is a rule of conduct, a contract, an ideal of reason, a rule of decision, a form of order; by Cicero that it is the agreement of reason and nature, the distinction between the just and the unjust, a command or prohibition; by Aquinas that it is an ordinance of reason for the common good, made by him who has care of the community, and promulgated; by Bacon that certainty is the prime necessity of law; by Hobbes that law is the command of the sovereign; by Spinoza that it is a plan of life; by Leibniz that its character is determined by the structure of society; by Locke that it is a norm established by the commonwealth; by Hume that it is a body of precepts; by Kant that it is a harmonizing of wills by means of universal rules in the interests of freedom; by Fichte that it is a relation between human beings; by Hegel that it is an unfolding or realizing of the idea of right." 47

Accepting the rough validity of Mr. Cairns' summaries of philosophical insights, is there any reason to suppose that these insights are incompatible, one with the other? Cannot the legal order be at one and the same time a "form of social control" (Plato), a "rule of conduct" and a "form of order" (Aristotle), a "command or prohibition" (Cicero) of the "sovereign" (Hobbes) or the "commonwealth" (Locke); a "plan of life" (Spinoza), "determined by the structure of society" (Leibniz); a "body of precepts" (Hume); and a "relation between human beings" (Fichte)? Even if we all meant exactly the same thing by the word "law," could we not subsume law under many broader categories, including those of "contract" (Aristotle), "rule of decision" (Aristotle), and a "way to the discovery of . . . the true reality of the social structure" (Plato)? And even if it be true that Plato, Aristotle, Cicero and Aquinas formulated their ideals of law in terms of reason and the good life, while Bacon stressed the need for certainty, and Kant and Hegel expressed an historical ideal of legal evolution towards universal justice and freedom, cannot all these views illuminate the possible goods achievable through the law? Why should we fall prey to the monolithic fallacy that only those who use a prescribed set of words can attain salvation?

If we view philosophy, including jurisprudence, not as a set of propositions but as a way of understanding, we may say that one philosophy is superior to another if it achieves a greater degree of generality

47. Cairns, Legal Philosophy from Plato to Heged 556 (1949). 
so that it can include other philosophies as special cases within a larger framework of convergent perspectives. Recognition of the relativity of definitions permits the establishment of a family of perspectives (e.g., Euclidean, Riemannian, and Lobachewskian geometries). ${ }^{48} \mathrm{~A}$ comprehensive legal philosophy can find room for the insights of many different thinkers.

Legal philosophy is not a bad play in which each actor clears the stage by killing off his predecessors. Rather is legal philosophy, like philosophy generally, a great cooperative exploration of possible perspectives (Weltanschauungen) through which life's many-faceted problems can be viewed. ${ }^{49}$ Progress in legal philosophy does not depend upon rejection of the insights that came to Plato and Aristotle, any more than progress in poetry depends upon rejection of Homer, or progress in music upon contempt for Bach and Beethoven. Nor is it necessary to assume, in the fashion popularized by Hegel and Pound, that every "school" (perish the word!) of jurisprudence supersedes its predecessors. The history of legal philosophy is not, as some of Pound's writings have suggested, a sad history of successive errors, each thesis producing, in Hegelian-Marxian fashion, its own antithesis and destruction, until, by a series of stages, we come to the ultimate product of the juristic mind, sociological jurisprudence, after which anything different must be considered as one of time's typographical errors.

More tolerance may give us more truth. The house of jurisprudence has many mansions. Of law and the legal order many questions may be asked. The seekers after "natural law," who have tried to formulate in legal patterns the most general needs of human society, are not contradicted or displaced when men turn to inquire into the historical forces that produce diverse legal systems in different lands and epochs. Those who have given us the logical analysis of legal terms that goes by the name of analytical jurisprudence never denied the role of legal sociology in exploring the social sources of legal orders and disorders. Indeed, the great exponents of analytical jurisprudence, Austin, Bentham, and Holmes, were precisely the men who called most cogently for scientific inquiry into the social context and consequences of law. Those who have earned the name of "realists" by drawing clear distinctions between the law that is and the law that ought to be do not obstruct efforts at social reform by their distinction. ${ }^{50}$ Rather, each line of exploration is likely to disclose landmarks which will prove of

48. The most comprehensive statement of the relativity of systems that I know of is to be found in the brief paper of Henry M. Sheffer on Notational Relativity in Proceedings of the Sixth International Congress of Philosophy 348-51 (1927).

49. The conception of philosophy here stated I have attempted to develop more fully in The Relativity of Philosophical Systems and the Method of Systematic Relativism, 36 J. of Philosophy 57 (1939).

50. See the incisive study of Garlan, Legal Realism and Justice (1941). 
value to other explorers moving in different directions and starting from different approaches.

Wilmon Sheldon has acutely observed that philosophers are generally right in what they affirm of their own vision and generally wrong in what they deny of the vision of others. Now it may be true that denying the vision of others adds controversy to the spice of life and thus draws attention to important views that would otherwise fail to attract serious consideration. And certainly it is only natural for proponents of new thoughts, and even more natural for the campfollowers of original thinkers, to claim for these thoughts dominion over the universe of ideas. But a saner perspective shows that no philosophical or jurisprudential doctrine has ever filled the space of our intellectual universe, and that the products of human thinking across a hundred centuries, all together, illuminate only a few of the darker corners of the world we seek to understand. It is the part of wisdom, in jurisprudence, as in science and philosophy generally, to avoid extravagant claims and to give those on whose thinking we build as much respect as we hope to deserve from those who come after us.

A synoptic vision which can find value in many perspectives is not to be confused with mushy-minded scissors-and-paste eclecticism. Stringing together the views of many men who followed divergent paths is a fruitless enterprise, productive only of a sense of complete futility and confusion. If the six blind men of Hindustan who reported on the elephant had each noted the direction of his approach and the point at which he made contact with the beast, the six reports might have been systematically coordinated and a correct, though incomplete, account of the animal might have emerged. So, too, if we took account of the different perspectives from which legal philosophers have approached the problem of the nature of law, we should not only be in a better position to appraise each of their contributions but we should be able to systematize their various insights and perhaps emerge with a more comprehensive, synoptic vision of the legal order than any past generation has enjoyed.

The judge who understands how two lawyers can disagree on the elementary facts of a simple case, why each lawyer thinks the other's precedents are not in point, and how they can differ even in their causal judgments, may achieve a higher level of understanding than the most brilliant of advocates. Similarly, the vision of legal philosophy as a family of possible perspectives upon the legal order may help us to achieve a broader and deeper understanding than is attained by even the most brilliant of jurisprudential advocates.

The systematization of possible logical systems outlined by Sheffer ${ }^{51}$

51. See note 48 supra. 
points to the possibility of a systematization of jurisprudential systems. The difficulties in such a task are serious. But if we face the difficulties resolutely, none of them appears insuperable.

\section{The Inarticulate Value Judgments of Legal Philosophers.}

The first difficulty in systematizing juristic perspectives lies in the fact that legal philosophers, like judges and human beings generally, do not ordinarily make explicit their own purposes or the value patterns out of which their purposes emerge. It therefore becomes necessary for those of us who seek to locate the perspective of Hobbes, Spinoza, Locke or Kant, for example, within a more comprehensive family of perspectives to understand what these men were driving at when they put forward their very different conceptions of law. If we appreciate the evils of civil warfare and anarchy which Hobbes experienced and portrayed so vividly, and if we consider his analysis of law and sovereignty as a persistent inquiry into the ways of avoiding these evils, we can hardly be satisfied with the fashionable practice of dumping Hobbes into a dustbin marked "defenders of despotism." For the evils that Hobbes saw are still before us, and though his analysis, as developed by Bentham, Austin, and Holmes, does not answer all juridical problems, it must be a part of any comprehensive view of law and the world order.

That Spinoza and his follower Locke were more concerned than Hobbes with the evils of tyranny and anxious to establish realms of civil liberty which demand respect even from governments, gives us, who are the heirs of Spinoza and Locke, as well as of Hobbes, the wherewithal to balance the needs of order and the needs of freedom in the difficult social problems that face us today.

Even the forbidding formalism of Kant comes to make practical sense if we appreciate Kant's concern with a problem which he saw more clearly a century and a half ago than many of our contemporary statesmen do today: the problem of how men pursuing radically different social goals and capable of destroying each other with the weapons of modern science can possibly evolve a pattern of living together in mutual respect, a pattern more fundamental than any of the things that mark off nation from nation, class from class, and man from man. ${ }^{52}$

\section{The Relativity of Definitions.}

Among the difficulties that stand in the way of a comprehensive view of the legal order is the naive view of definitions as propositions

52. I think the human objectives of Kant's juridical quest become clearest in his Idea of a Universal History from a Cosmopolitical Point of View (1784) and his Essay on Perpetual Peace (1795). See Kant's Principles of Politics (Hastie ed. 1891). 
which are true or false. All of the endless arguments as to whether international law is really law, whether an unenforced statute is really law, etc., depend for their continuance upon the notion that only one definition of law can be correct. Once we recognize that a definition is, strictly speaking, neither true nor false but rather a resolution to use language in a certain way,,$^{53}$ we are able to pass the only judgment that ever needs to be passed on a definition, a judgment of utility or inutility. We can then recognize that Holmes' definition of law as the way courts decide cases is an instrument of tremendous value for the practicing lawyer or for any critical observer of the role played by courts in modern civilization. On the other hand, we may frankly admit that the definition has very slight utility to an anthropologist investigating the ways in which Eskimos deal with murder or divorce. Clarity requires not that all of us forever adhere to a single definition but that we make clear what definition of law we are using in any given context, so that what we say can be fairly translated into other people's universes of discourse.

\section{The Theory of Translation, and the Relativity of Nonsense}

The true significance of Einstein's general theory of relativity, as we have noted, ${ }^{54}$ is not that it calls attention to the long-recognized diversity of physical perspectives, but that it makes possible a translation from any perspective into any other perspective.

Can we translate a thought from one social perspective to another?

Certainly we try to do this whenever we translate from one language to another. Sometimes we succeed. When we fail, it is often because we forget that a language embodies the history of a people's thinking and that different people have partitioned the world in different ways.

Mark Twain, when he saw what French translators had done to his Jumping Frog story, was moved to words of despair:

"When I say, 'Well, I don't see no p'ints about that frog that's any better'n any other frog,' is it kind, is it just, for this Frenchman to try to make it appear that I said, 'Eh bien! I no saw not that that frog had nothing of better than each frog'? I have no heart to write more. I never felt so about anything before." ${ }_{55}$

Every lawyer who has seen his views of the law or the facts of a case restated or summarized by a judge who does not agree with them knows how Mark Twain felt.

53. See F. S. Cohen, Transcendental Nonsense and the Functional Approach, 35 CoL. L. Rev. 809, 835-6 (1935) ; M. R. Cohen, On Absolutisms in Legal Thought, 84 U. of PA. L. REv. 681 (1936).

54. See Note 4 supra.

55. Mark Twain, The Family Mark Twain 1080 (1935) ("The Jumping Frog: In English. Then in French. Then clawed back into a civilized language once more by patient, unremunerated toil.") 
Of course, some translators do better than others. A particularly fine performance was given a few years ago at a labor convention in El Paso attended by labor delegates from both sides of the Rio Grande. Those from the north side of the river made matter-of-fact speeches in English about wage increases and the reduction of working hours. Those from across the stream made impassioned speeches in Spanish about the role of labor unions in the social revolution. The translator was equal to the occasion. All the English speeches, when translated into Spanish, were about the social revolution, and all the Spanish speeches, when translated into English were about hours and wages. Mutual appreciation and understanding grew. Bonds of harmony were established that would certainly have been smashed if Mark Twain's Jumping Frog translator had sneaked into the El Paso convention.

Only in mathematics do we find perfect translations - the sort of thing that enables us to translate any proposition about a straight line in Euclidean geometry into an equivalent proposition about a curve in Riemannian geometry. But outside of mathematics, though we live in a world of imperfections, some imperfections are worse than others. Those of us who take our law in realistic doses are less likely to misunderstand writers on natural law if we translate their propositions about "law" into equivalent propositions about "legal ideals." Operating with such formulae of translation law students who have been prone to distrust all discourse written in unfamiliar terms are sometimes amazed to learn how much good sense was devoted centuries ago to some of the problems that still trouble us.

As yet this sort of translation among the different tongues of jurisprudence is mostly in the inarticulate stage of "hunch" and "intuition." The achievements of modern mathematics and physics, however, give ground for hoping that we shall some day achieve a powerful new organon for mutual understanding,- - a theory of translation. Until that day comes, we may do well to remember that no two philosophers and no two jurists can ever contradict each other unless they are talking about the same thing, and that there is no reason to believe that those who use the same words necessarily mean the same things. In fact, I find it to be a fair working assumption that when a legal philosopher says something that I recognize to be absurd, the statement probably meant something different to him than it means to me. As an appendix to a theory of translation we need a doctrine of the relativity of nonsense.

Until mathematicians become lawyers or lawyers become mathematicians, we may at least cultivate the spirit of tolerance which begins by recognizing that what is worth saying can be said in any language. 